\title{
Assessment of Genetic Fidelity of in vitro Raised Plants in Swertia chirayita through ISSR, RAPD analysis and Peroxidase Profiling during Organogenesis
}

\author{
Vikas Sharma ${ }^{1}$, Nidhi Belwal' ${ }^{2}$ Barkha Kamal $^{2}$, Anoop Kumar Dobriyal ${ }^{3}$, Vikash Singh \\ Jadon $^{2^{*}}$. \\ ${ }^{1}$ Arni University - Biotechnology, Kathgarh Indora HP, India; ${ }^{2}$ SBSPGI, Balawala, Dehradun, India $;{ }^{3} H N B G$ \\ Univ Campus Pauri, Pauri Garhwal, India.
}

\begin{abstract}
An efficient in vitro regeneration protocol for medicinally important herb Swertia chirayita was developed and the genetic fidelity was assessed using RAPD and ISSR markers. The best shoot regeneration was observed on MS basal supplemented with $1.0 \mathrm{mg} / \mathrm{L}$ Benzyl amino purine (BAP) in combination with Indole-3-acetic acid (IAA) (0.5 mg/L) that resulted in the increase by multiplication rate (7.65) with an average of 33.33 numbers of shoots and average shoot length of $2.70 \mathrm{~cm}$. It was further enhanced by the addition of adenine sulfate $(0.007 \%)$ that resulted in an average of 42 shoots per clum with $4.13 \mathrm{~cm}$ of average shoot length and the increase in multiplication fold to 9.75 that further resulted in the reduced use of other cytokinins and auxins. The rooting was nearly $100 \%$ on $1 / 4 \mathrm{MS}$ augmented with $1.0 \mathrm{mg} / \mathrm{L}$ Indole butyric acid with maximum average root length of $5.1 \mathrm{~cm}$. Plantlets were successfully acclimatized with $85-90 \%$ survival rate. Ascorbate peroxidase activity increased with the maximum activity during the shoot multiplication. Clonal fidelity has been checked by two marker systems ISSR and RAPD and regenerated plants showed high clonal fidelity.
\end{abstract}

Keywords: Swertia chirayita; micropropagation; adenine sulfate; ascorbate peroxidase; RAPD; ISSR.

\footnotetext{
*Authors for correspondence: biotech_vikas@rediffmail.com
} 


\section{INTRODUCTION}

Swertia chirayita (Roxb. ex Fleming) H. Karst. is an important medicinal herb belonging to family gentianaceae. The plant is indigenous to temperate Himalayas and is used as a bitter tonic in treatment of fever and for curing various skin diseases ${ }^{1}$.

All the parts of plants - leaves, stems, flowers and roots are useful for the remedial measures and reported in Indian pharmaceutical keycodex, the British and the American pharmacopoeias and in different traditional systems of medicines such as the Ayurveda, Unani and Siddha. Increasing pharmaceutical demand of the species has led to over exploitation and unsustained and destructive harvesting from the wild source and hence lowering the number of the plant in natural habitat. Therefore alternative means of propagation are highly recommended for this plant. However, one of the serious problems that discourage agrotechnology development in Swertia chirayita is low seed set, low viability, germination percentage of the seeds and the necessarily delicate field handling of the seedlings. Tissue culture offers the opportunity to develop new germplasm and it is better adapted to the changing demands ${ }^{2-4}$.

There are few reports on micropropagation of Swertia chirayita through axillary shoots ${ }^{5}$, in vitro grown seedlings ${ }^{6}$, nodal meristems and immature seed culture ${ }^{7}$. The production of reactive oxygen species (ROS) has been associated with plant recalcitrance during in vitro culture (Benson, $2000)^{8}$. The role of antioxidant enzymes during organogenesis and somatic embryogenesis in some species have been studied in past few years ${ }^{9-14}$. But to the best of our knowledge, it is the first report on Swertia chirayita regeneration and genetic authentication revealed by two marker sytems (ISSR/RAPD) as well as biochemical and kinetic parameters studied in vitro.

\section{MATERIALS AND METHODS}

\section{Plant material}

The juvenile plants of Swertia chirayita grown ex situ were collected from Hitech Forest Nursery, Deovan, Chakrata (1400 meters), Uttarakhand, India, during the month of July. Seed samples were submitted to NBPGR, Pusa Campus, New Delhi, for its germplasm conservation and the accession number (VS-03-IC- 567642) for the same was obtained. The flowering plants after drying were prepared for herbarium which was submitted to Botanical Survey of India, Northern Regional Centre, Dehradun (BSD) for identification. upto species level and plants were identified as Swertia chirayita (Roxb. Ex Fleming) (VS 02) Family-Gentianaceae (Acc.No.113342) and Swertia cordata (G. Don) C.B.Clarke (VS 03) Family-Gentianaceae (Acc.No.113343). Swertia cordata was used for the DNA analysis as an outlier for RAPD and ISSR analysis.

Young and tender shoots of approximately $1-1.5$ $\mathrm{cm}$ were excised from 45 days old plant. Nodal explants were thoroughly washed in running tap water, and then treated with Tween-20 solution for 10 min, washed 2 - 3 times with sterile distilled water, treated with $0.01 \% \mathrm{HgCl}_{2}$ solution for 5 min and washed with sterile distilled water $4-5$ times.

\section{Media and PGRs}

The basal media consisted of MS macro and micro salts, $2.5 \%$ sucrose and $0.2 \%$ clarigel (all chemicals are procured from Merck, Darmstadt, Germany). The $\mathrm{pH}$ of the medium was adjusted to $5.8 \pm 2$ prior to adding clarigel. The medium was autoclaved at $121^{\circ} \mathrm{C}$ and $1.06 \mathrm{~kg} \mathrm{~cm}^{-2}$ for $15 \mathrm{~min}$. Then explants were cultured on Murashige and Skoog (1962; MS $)^{15}$ medium containing N6benzyladenine (BAP) , $\alpha$-naphthalene-acetic acid (NAA), Indole- 3- acetic acid (IAA), Indole butyric acid (IBA) at various concentrations and combinations or alone for axillary bud induction, shoot proliferation and shoot elongation and root induction. Additives (Adenine sulphate and Dglutamine) in varying concentration of $0.001 \%$ to $0.010 \%$ were tested in combination with BAP $(1 \mathrm{mg} / \mathrm{L})$ for best in vitro shoot multiplication .

\section{Culture Conditions}

All cultures were incubated in a culture room under 16-h photoperiod with light intensity of 40 $\mu \mathrm{mol} \mathrm{m} \mathrm{m}^{-2} \mathrm{~s}^{-1}$ provided by cool white fluorescent lamps, $50 \pm 5 \%$ humidity and temperature of $25 \pm$ $2{ }^{\circ} \mathrm{C}$.

\section{Subculture \& Rooting}

Subculturing was performed at an interval of 3 to 4 weeks. In the subsequent passages the regenerating masses were divided into pieces and subcultured onto the same medium for further multiplication. Elongated shoots $(>4.0 \mathrm{~cm})$ derived from actively multiplying cultures were separated and cultured on MS medium supplemented with indolebutyric 
acid (IBA) or IAA for rooting in varying concentrations.

\section{Hardening}

After 30 days, rooted plantlets were removed from culture vessels, washed thoroughly with sterile distilled water to remove traces of clarigel and planted in glass jar with mixture of sterile soil, sand and solarite (1:1:1). The potted plants were irrigated with MS basal salt solution, $1 / 4$ MS devoid of sucrose every four days for three weeks. After 3 weeks, plants were kept under shade for $15 \mathrm{~d}$ and then transferred to greenhouse.

\section{Statistical Analysis}

Data collected was analyzed using CRD design of experiments, as it is one of the most widely used design in case of tissue culture experiments (controlled set of conditions and for homogenous materials). Minimum of 16 replicates per treatment were used and each replicate consists of at least 2 explants in each repetition of experiment thrice. Data collected was subjected to analysis of variance (ANOVA), to find out the significance of differences observed in morphogenic responses of Swertia chirayita. Degree of variation was shown by standard error and critical difference at $5 \%$. Significance level was tested at $1 \%, 0.5 \%$ and $0.1 \%$ level.

\section{Peroxidase Estimation}

For estimation of total protein content and enzyme activity, tissue $(0.5 \mathrm{~g})$ was homogenized in $50 \mathrm{mM}$ phosphate buffer $(\mathrm{pH}$ 7.0) containing $1 \mathrm{mM}$ EDTA, $\quad 0.05 \%$ Triton X-100, $1 \mathrm{mM}$ polyvinylpyrrolidone, and $1 \mathrm{mM}$ ascorbate. After centrifugation of homogenate at $5000 \mathrm{~g}$ for $20 \mathrm{~min}$ at $4{ }^{\circ} \mathrm{C}$, the supernatant was used to measure the activities of peroxidase enzymes. Protein estimation was carried out by method of Lowry et al. $(1951)^{16}$. Ascorbate peroxidise activity (APX; E.C.1.11.1.7) was measured as the rate of hydrogen peroxide-dependent oxidation of Odianisidine $e^{17}$. Specific activity was calculated using an extinction coefficient of $\mathrm{e}=11.3 \mathrm{M}^{-1} \mathrm{~cm}^{-1}$ for $\mathrm{H}_{2} \mathrm{O}_{2}$. Five concentrations of O-dianisidine viz. $0.102 \mathrm{mM}, 0.204 \mathrm{mM}, 0.306 \mathrm{mM}, 0.408 \mathrm{mM}$ and $0.510 \mathrm{mM}$ were used to evaluate the rate of reaction. Reaction was carried out in a total of $4 \mathrm{ml}$ mixture containing phosphate buffer $(0.1 \mathrm{M}$, pH$6.5), \mathrm{H}_{2} \mathrm{O}_{2}(0.2 \mathrm{M})$, varying concentrations of $\mathrm{O}$ dianisidine and crude plant extract. The change in absorbance was recorded at $470 \mathrm{~nm}$ and the reaction was initiated by the addition of crude enzyme fraction $(0.2 \mathrm{ml})$. To determine the $K_{m}$ and $V_{\max }$ values, the double reciprocal curve (Lineweaver Burk Plot) was plotted for reciprocal values of substrate concentrations $(1 /[\mathrm{S}])$ versus reciprocal values of initial velocity (1/ [V]).

\section{RAPD analysis}

Clonal fidelity of in vitro raised plants was carried out by performing rapid amplified polymorphic DNA (RAPD). DNA was isolated as per the protocol developed by Sharma et al. $(2010)^{18}$. Approximately $1 \mathrm{~g}$ leaves of in vitro raised plants and in vivo plants were pulverized in liquid nitrogen. After ethanol precipitation, DNA was resuspended in $0.002 \mathrm{~cm}^{3}$ of $1 \times$ TE buffer $(\mathrm{pH}$ 8.0). The DNA was quantified spectrophotometrically by taking the absorbance at $260 \mathrm{~nm}$. Agarose gel electrophoresis was done and DNA bands were visualized under UV radiation. RAPD assay was carried out by using 30 single random decamer primers following the method of Williams et al. $(1990)^{19}$. The reaction mixture contained $2.5 \mu \mathrm{M}$ of each dNTP (Banglore Genei), 1X Taq polymerase buffer (Banglore Genei), 25 $\mathrm{mM} \mathrm{MgCl}_{2}, 25 \mu \mathrm{m}$ primer, $15 \mathrm{ng}$ DNA template and 1 unit of Taq DNA polymerase (Banglore Genei). The reaction was overlaid with mineral oil and amplification was performed. The amplification was performed by initial denaturation of template DNA at $94^{\circ} \mathrm{C}$ for $1 \mathrm{~min}$ followed by 38 cycles of $1 \mathrm{~min}$ at $94^{\circ} \mathrm{C} ; 1 \mathrm{~min}$ at $35^{\circ} \mathrm{C} ; 0.45 \mathrm{~min}$ at $72^{\circ} \mathrm{C}$ and final cycle having the final extension time of $8 \mathrm{~min}$ at $72^{\circ} \mathrm{C}$, using the fastest possible transmission between each temperature. Amplified fragments generated following RAPD amplification were separated on $1.5 \%$ agarose gel using $1 \mathrm{X}$ TBE buffer and ethidium bromide at the concentration of $5 \mathrm{mg} / \mathrm{ml}$. The gel was visualized under UV light using UviTech Gel Documentation system. The primer sequences used were:

\begin{tabular}{|l|l|}
\hline Primer & Sequence \\
\hline $\mathrm{M}-29$ & CCGGCCTTAC \\
\hline $\mathrm{M}-31$ & CCGGCCTTCC \\
\hline $\mathrm{M}-33$ & CCGGCTGGAA \\
\hline $\mathrm{M}-119$ & ATTGGGCGAT \\
\hline $\mathrm{M}-82$ & GCGCCCGAGG \\
\hline $\mathrm{M}-83$ & GGGCTCGTGG \\
\hline $\mathrm{M}-110$ & TAGCCCGCTT \\
\hline $\mathrm{M}-116$ & TACGATGACG \\
\hline
\end{tabular}




\begin{tabular}{|l|l|}
\hline M-186 & GTGCGTCGCT \\
\hline M-188 & GCTGGACATC \\
\hline M-191 & CGATGGCTTT \\
\hline M-131 & GAAACAGCGT \\
\hline M-132 & AGGGATCTCC \\
\hline M-147 & GTGCGTCCTC \\
\hline OPA-2 & TGCCGAGCTG \\
\hline OPA-8 & GTGACGTAGG \\
\hline OPA10 & GTGATCGCAG \\
\hline OPA-4 & AATCGGGCTG \\
\hline OPB1 & GTTTCGCTCC \\
\hline OPB2 & TGATCCCTGG \\
\hline OPB3 & TGATCCCTGG \\
\hline OPB4 & GGACTGGAGT \\
\hline OPB5 & TGCGCCCTTC \\
\hline OPB6 & TGCTCTGCCC \\
\hline OPB7 & GGTGACGCAG \\
\hline OPB8 & GTCCACACGG \\
\hline OPA1 & CAGGCCCTTC \\
\hline
\end{tabular}

\begin{tabular}{|l|l|}
\hline UBC-840 & GYA \\
\hline AYT AGA GAG AGA GAG \\
\hline
\end{tabular}

Each $50 \mu \mathrm{l}$ PCR reaction mixture consisted of 38 $\mu \mathrm{l}$ sterile ddH2O, $5 \mu \mathrm{l}$ of 10X PCR buffer, $3 \mu \mathrm{l}$ of $\mathrm{MgCl}_{2}(25 \mathrm{mM}), 1.5 \mu \mathrm{l}$ of dNTP (10 mM total, 2.5 $\mathrm{mM}$ each), $1 \mu \mathrm{l}$ of primer $(50 \mu \mathrm{M}), 0.2 \mu \mathrm{l}$ of Taq polymerase (Genei, Banglaore) $(5 \mu / \mu \mathrm{l})$, and $1.3 \mu \mathrm{l}$ of template DNA. A thermal cycler (Eppendrof, Germany) was used and an initial Denaturation step was at $94^{\circ} \mathrm{C}$ for $5 \mathrm{~min}$ followed by $35-45$ cycles with $1 \mathrm{~min}$ at $92^{\circ} \mathrm{C}$ (denaturation), $1 \mathrm{~min}$ at $35^{\circ} \mathrm{C}$ to $50^{\circ} \mathrm{C}$ (annealing), and $2 \mathrm{~min}$ at $72^{\circ} \mathrm{C}$ (extension). The annealing temperature was $5^{\circ} \mathrm{C}$ less than the primer $\mathrm{Tm}(\mathrm{Tm}-5)$. An extension cycle at $72{ }^{\circ} \mathrm{C}$ for $5 \mathrm{~min}$ was used to terminate the reaction before a final soak at $4^{\circ} \mathrm{C}$. The PCR products were visualized in $2.0 \%$ gels with $50 \%$ regular agarose and $50 \%$ metaphor agarose in $1 \mathrm{X}$ TBE, stained with ethidium bromide.

\section{ISSR analysis}

The 19 ISSR primers were initially screened to amplify the inter-repeat regions in the genomic DNA of tissue cultured plantlets and the mother plant genomic DNA using standard PCR procedures with minor modifications. A total of 10 ISSR primers were finally selected from previously done ISSR studies on Swertia ${ }^{20}$.

\begin{tabular}{|l|l|}
\hline Primer & Sequence \\
\hline UBC-807 & $\begin{array}{l}\text { AGA GAG AGA GAG AGA } \\
\text { UBC-807 }\end{array}$ \\
\hline UBC-809 & $\begin{array}{l}\text { AGA GAG AGA GAG AGA } \\
\text { GG }\end{array}$ \\
\hline UBC-810 & $\begin{array}{l}\text { GAG AGA GAG AGA GAG } \\
\text { AT }\end{array}$ \\
\hline UBC-811 & $\begin{array}{l}\text { GAG AGA GAG AGA GAG } \\
\text { AC }\end{array}$ \\
\hline UBC-812 & GAGAGAGAGAGAGAGAA \\
\hline UBC-818 & $\begin{array}{l}\text { CAC ACA CAC ACA CAC } \\
\text { AG }\end{array}$ \\
\hline UBC-820 & $\begin{array}{l}\text { GTG GTG TGT GTG TGT } \\
\text { GTC }\end{array}$ \\
\hline UBC-830 & $\begin{array}{l}\text { TGT GTG TGT GTG TGT } \\
\text { GG }\end{array}$ \\
\hline UBC-836 & AGA GAG AGA GAG AGA \\
\hline
\end{tabular}

Amplification with each random primer and ISSR primer was repeated 3 times and those primers that produced reproducible and consistent bands were selected for fidelity check. The results were expressed as means $\pm \mathrm{SE}$ of three independent replicates of independent experiments. All bands scored were recorded as present or absent for each DNA sample and the molecular weight and similarity index was estimated using Gene profiler software. All the randomly selected samples were clustered into two major clusters. The major cluster I comprising of ten samples, while the minor cluster II contained three samples. The data output from GENE PROFILER 4.05 was used to process our binomial data set using PopGen 32 statistical package. The resulting data set was then used to create a distance matrix, which was used as an input file for Popgen 32.

\section{RESULTS \\ Plant material}

Young juvenile, disease free and healthy plants as well as seeds of Swertia chirayita were selected and procured from Hi-tech Forest Nursery, Deoban (Chakrata) and Forest Nursery, Patalthod, Munsiyari, Uttarakhand respectively.

\section{Effect of BAP on shoot bud induction}

Initial sets of experiments were laid to study the effect of MS basal medium augmented with BAP 
(0.5-3.0 $\mathrm{mg} / \mathrm{L})$ with MS basal medium as control. The morphogenic differentiation of explant towards axillary bud proliferation was markedly influenced by the concentration of growth regulator (BAP) in the medium. The number of shoots induced per nodal explant was recorded regularly after 3-4 weeks that showed a significant variation in response for different concentrations of BAP. A maximum number of 6-7 shoot buds were induced per inoculated nodal explant on MS basal medium supplemented with BA $(1.0 \mathrm{mg} / \mathrm{L})$ (Fig 1A). The number and length of shoots decreased with the increase and decrease of the BAP concentration from $1.0 \mathrm{mg} / \mathrm{L}$.

\section{Synergistic effect of cytokinins and auxins on shoot multiplication and elongation}

BAP $(1.0 \mathrm{mg} / \mathrm{L})$ in combination with IAA (0.25$2.0 \mathrm{mg} / \mathrm{L})$, IBA $(0.25-2.0 \mathrm{mg} / \mathrm{L})$ and NAA (0.25-
$2.0 \mathrm{mg} / \mathrm{L}$ ) were tried for determining the multiplication potential of shoots. The combination of BAP with different auxins (IAA, NAA \& IBA) showed a significant variation for the number of shoots regenerated and. Though the presence of $1.0 \mathrm{mg} / \mathrm{L} \mathrm{BAP}$ and $0.5 \mathrm{mg} / \mathrm{L} \mathrm{IAA} \mathrm{was}$ found to be best for the shoot multiplication (33 \pm 0.67 average number of shoots); however, there was no effect on the length of shoot (Table 1, Figure $1 B \& C$ ). The effect of BAP in combination with IAA was higher as compared to BAP alone on multiplication fold. An average of $28.67 \pm 0.88$ shoots with $5.25 \%$ multiplication fold was attained with MS basal medium supplemented with BAP $(1.0 \mathrm{mg} / \mathrm{L})$ and $0.5 \mathrm{mg} / \mathrm{L}$ NAA with a length of $2.07 \mathrm{~cm} .31 \pm 0.58$ average numbers of shoots were recorded for IBA $(0.5 \mathrm{mg} / \mathrm{L})$ but the length of the shoots was observed to be $2.67 \mathrm{~cm}$.

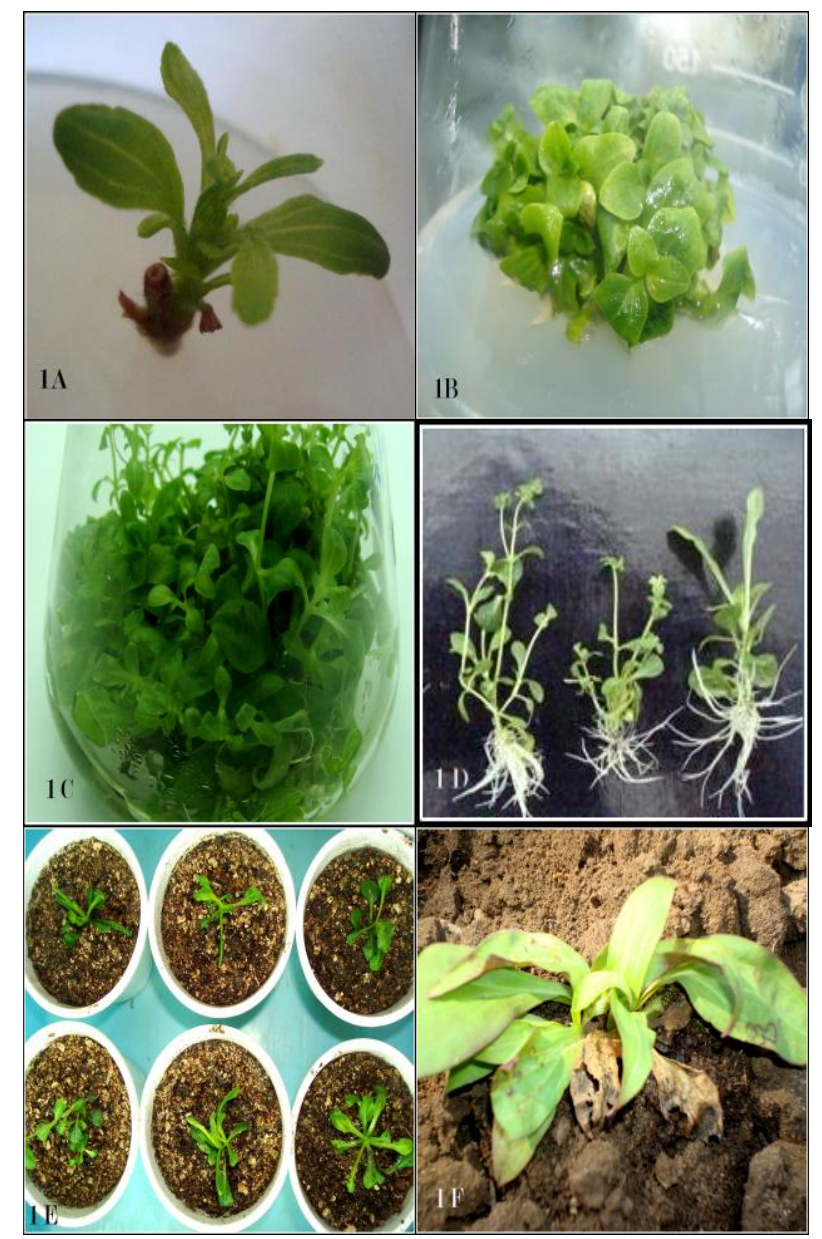

Figure 1. In vitro regeneration of Swertia chirayita from nodal explants: $A$ - initiation of culture; $B$ and $C$ - multiple shoots formation; $D$ - rooting of regenerated shoots; $E$ and $F$ - hardened plantlets in sterile soil, sand and Vermiculite mixture for $20 \mathrm{~d}$. 
Table 1: Effect of PGRs and adenine sulfate on in vitro shoot propagation. 4-5 explant per flask were included and data was recored after five weeks interval.MS Basal Medium Supplemented with $1.0 \mathrm{mg} / \mathrm{L} \mathrm{BAP}+2.5 \%$ Sucrose All plant growth regulator were used in $\mathrm{mg} / \mathrm{L}$ concentration of the medium. Each value represents mean \pm SD. + mark denotes magnitude of response.--mark denotes no response. Data was significant at $0.1 \%$.

\begin{tabular}{|c|c|c|c|c|c|c|}
\hline IAA & IBA & NAA & AS & Shoot No. & Shoot length $(\mathrm{cm})$ & Relative Callusing \\
\hline 0.25 & -- & -- & -- & $27.67 \pm 0.88$ & $2.40 \pm 0.15$ & + \\
\hline 0.5 & -- & -- & -- & $33.33 \pm 0.67$ & $2.70 \pm 0.06$ & + \\
\hline 1.0 & -- & -- & -- & $31.33 \pm 0.67$ & $2.27 \pm 0.15$ & ++ \\
\hline 1.5 & -- & -- & -- & $29.33 \pm 0.67$ & $1.77 \pm 0.09$ & ++ \\
\hline 2.0 & -- & -- & -- & $24.00 \pm 1.15$ & $1.63 \pm 0.22$ & ++ \\
\hline-- & 0.25 & -- & -- & $29.33 \pm 0.88$ & $2.33 \pm 0.12$ & + \\
\hline-- & 0.5 & -- & -- & $31.00 \pm 0.58$ & $2.67 \pm 0.03$ & ++ \\
\hline-- & 1.0 & -- & -- & $26.00 \pm 1.15$ & $1.97 \pm 0.07$ & +++ \\
\hline-- & 1.5 & -- & -- & $23.00 \pm 0.58$ & $1.70 \pm 0.06$ & +++ \\
\hline-- & 2.0 & -- & -- & $18.00 \pm 0.58$ & $1.50 \pm 0.06$ & +++ \\
\hline-- & -- & 0.25 & -- & $26.33 \pm 0.88$ & $2.30 \pm 0.26$ & + \\
\hline-- & -- & 0.5 & -- & $28.67 \pm 0.88$ & $2.07 \pm 0.09$ & + \\
\hline-- & -- & 1.0 & -- & $27.00 \pm 0.58$ & $1.80 \pm 0.10$ & ++ \\
\hline-- & -- & 1.5 & -- & $26.00 \pm 1.15$ & $1.93 \pm 0.03$ & +++ \\
\hline-- & -- & 2.0 & -- & $24.00 \pm 1.15$ & $1.87 \pm 0.13$ & ++ \\
\hline-- & -- & -- & $0.005 \%$ & $27.33 \pm 0.88$ & $2.37 \pm 0.15$ & -- \\
\hline-- & -- & -- & $0.006 \%$ & $31.33 \pm 0.67$ & $2.60 \pm 0.12$ & -- \\
\hline-- & -- & -- & $0.007 \%$ & $42.00 \pm 1.76$ & $4.13 \pm 0.15$ & -- \\
\hline-- & -- & -- & $0.008 \%$ & $35.00 \pm 1.15$ & $3.23 \pm 0.18$ & -- \\
\hline-- & -- & -- & $0.009 \%$ & $34.67 \pm 0.33$ & $2.43 \pm 0.20$ & + \\
\hline
\end{tabular}

\section{Effect of additives on shoot multiplication}

A significant variation in shoot multiplication and elongation was observed when shoots were inoculated on medium supplemented with BAP and adenine sulphate. Maximum number of healthy and profuse shoot emergence was observed with MS basal media along with 1.0 $\mathrm{mg} / \mathrm{L}$ BAP supplemented with $0.007 \%$ adenine sulfate and MS basal medium supplemented with $1.0 \mathrm{mg} / \mathrm{L}$ BAP along with $0.005 \%$ d-glutamine. The medium supplemented with adenine sulfate showed a significant increase in the rate of shoot multiplication, showing more than 40 number of shoots with 9.75 fold increase in multiplication and highest shoot length $(4.13 \mathrm{~cm}$ ) (Figure $1 C$ ). There was no significant variation in the growth rate when d-glutamine was used (data not shown).

\section{In vitro Rooting \& Hardening}

The elongated shoots were excised from shoot clumps and inoculated on $1 / 4$ MS medium containing different concentrations of IAA, NAA and IBA (Table 2). It was found that decreasing MS strength reduced callusing but enhanced rooting. However, $1 / 4 \mathrm{MS}$ medium augmented with $1.0 \mathrm{mg} / \mathrm{L}$ IAA showed $100 \%$ rooting. (31 average numbers and $5.1 \mathrm{~cm}$ average length). A rooting response of $94 \%$ was obtained on $1.0 \mathrm{mg} / \mathrm{L}$ IBA supplemented $1 / 4$ MS medium with 30 roots on an average per shoot propagule. Effect of NAA was lower as compared to IBA and IAA for in vitro rooting as it produced less percent response $(85 \%)$ with a maximum number (25.00) and length of roots was also reduced $(3.8 \mathrm{~cm}$ ) (Figure $1 D$; Table 2 ). The rooted plants were suspended in $1 / 4 \mathrm{MS}$ supplemented with $24.5 \mu \mathrm{M}$ IBA with the help of 
sterile filter bridge in dark for $2 \mathrm{~d}$ and the developed roots turned out to be more thick and strong. Plantlets were kept for 2-3 weeks for in vitro hardening (Figure $1 E \& F$ ). Later, they were transferred in polybags and kept in mist chamber at relative humidity of $80-90 \%$ and temperature $30^{\circ} \mathrm{C} \pm 2^{\circ} \mathrm{C}$ and were transferred into polybags containing sand:soil:vermiculite in 1:1:1 ratio.

Table 2.: Effect of auxins in $1 / 4 \mathrm{MS}$ media on in vitro rooting of microshoots. All plant growth regulator were used in $\mathrm{mg} / \mathrm{L}$ concentration of the medium. Each value represents mean \pm SE. + mark denotes magnitude of response.-mark denotes no response. Data was significant at $0.1 \%$.

\begin{tabular}{lllllc}
\hline IAA & IBA & NAA & Root No. & Root length $(\mathrm{cm})$ & Relative Callusing \\
\hline 0.5 & -- & -- & $16.0 \pm 1.15$ & $3.1 \pm 0.06$ & -- \\
1.0 & -- & - & $31.7 \pm 1.20$ & $5.1 \pm 0.09$ & - \\
1.5 & -- & -- & $28.0 \pm 1.15$ & $3.9 \pm 0.18$ & - \\
2.0 & -- & - & $15.0 \pm 0.58$ & $3.0 \pm 0.50$ & - \\
2.5 & & & $15.0 \pm 0.5$ & $2.5 \pm 0.17$ & + \\
-- & 0.5 & -- & $14.0 \pm 1.15$ & $2.5 \pm 0.07$ & - \\
-- & 1.0 & -- & $30.0 \pm 1.15$ & $4.3 \pm 0.07$ & - \\
-- & 1.5 & -- & $23.0 \pm 0.58$ & $3.4 \pm 0.12$ & + \\
- & 2.0 & -- & $17.3 \pm 1.33$ & $3.1 \pm 0.06$ & + \\
-- & 2.5 & -- & $10.0 \pm 1.00$ & $2.4 \pm 0.12$ & - \\
-- & -- & 0.5 & $15.0 \pm 0.58$ & $2.2 \pm 0.20$ & - \\
-- & -- & 1.0 & $25.0 \pm 0.58$ & $3.8 \pm 0.06$ & - \\
-- & -- & 1.5 & $20.3 \pm 0.88$ & $2.8 \pm 0.12$ & + \\
-- & -- & 2.0 & $12.0 \pm 1.15$ & $2.1 \pm 0.06$ & + \\
-- & -- & 2.5 & $9.3 \pm 1.45$ & $1.6 \pm 0.09$ & + \\
\hline
\end{tabular}

\section{Peroxidase Profiling}

The highest peroxidase activity was observed during the multiplication of the in vitro grown shoots of $S$. chirayita with basal MS supplemented with $0.007 \%$ adenine sulphate (Table 3 ).

Table 3 Activities [mol(H2O2) g-1(protein) min-1], Enzyme units (Kat/cm3), $\mathrm{V}_{\max }$ and $\mathrm{K}_{\mathrm{m}}$ of peroxidase observed during shoot initiation, multiplication and regenerated shoots.

\begin{tabular}{|c|c|c|c|c|c|c|}
\hline $\begin{array}{l}\text { Regeneration } \\
\text { Phase }\end{array}$ & $\begin{array}{l}\text { Total } \\
\mathrm{mg} / \mathrm{ml}\end{array}$ & Protein & $\begin{array}{l}\text { Specific } \\
\text { Activity }\end{array}$ & $\begin{array}{l}\text { Enzyme Units } \\
\mathrm{Kat} / \mathrm{cm}^{3}\end{array}$ & $\mathrm{~V}_{\max }$ & $\mathrm{K}_{\mathrm{m}}$ \\
\hline Shoot Initiation & 0.026 & & 0.032 & 82 & 0.029 & 0.192 \\
\hline $\begin{array}{l}\text { Shoot } \\
\text { multiplication }\end{array}$ & 0.053 & & 0.061 & 87 & 0.058 & 0.357 \\
\hline $\begin{array}{l}\text { Regenerated } \\
\text { Shoots }\end{array}$ & 0.113 & & 0.071 & 85 & 0.063 & 0.117 \\
\hline \multicolumn{2}{|c|}{$\begin{array}{l}\text { Correlation Coefficient } R 2 \\
\left(K_{m} / V_{\max }\right) \\
\text { Calculated value }\end{array}$} & & & & & $0.4868 * *$ \\
\hline
\end{tabular}

\section{ISSR and RAPD analysis}

A total of 35 random decamar primers screened, 25 primers resulted in the amplification of monomorphic loci (Figure $2 A \& 2 B$ ). The number of scorable bands with all primer ranged from 1 to 7 bands in M-119. The fragment size ranged from 0.3 to $1.5 \mathrm{~kb}$ with highest bp size in OPB-4 (0.4$1.5 \mathrm{~kb})$. The in vitro raised shoot propagules were assessed for genetic analysis through similarity index and cluster analysis along with the parental plants and showed about $97 \%$ of similarity, and thus show high uniformity throughout the stock (Figure 2C).

The results of the present study using ISSR markers showed a low degree of polymorphism and high level of genetic similarity within the samples. The ISSR analysis showed the similar trend of genetic diversity as compared to RAPD phylogenetic analysis that also showed a similar trend and no significant variation within the 
samples generated through in vitro multiplication, rooting and acclimatization. Out of 19 ISSR primers used 10 were found to be monomorphic with $95-98 \%$ similarity as revealed by the cluster analysis using UPGMA (Unweighted Pair Group
Method with Arithmetic Mean) method (Figure 3A). Major cluster was having $96 \%$ similarity with the cluster II.
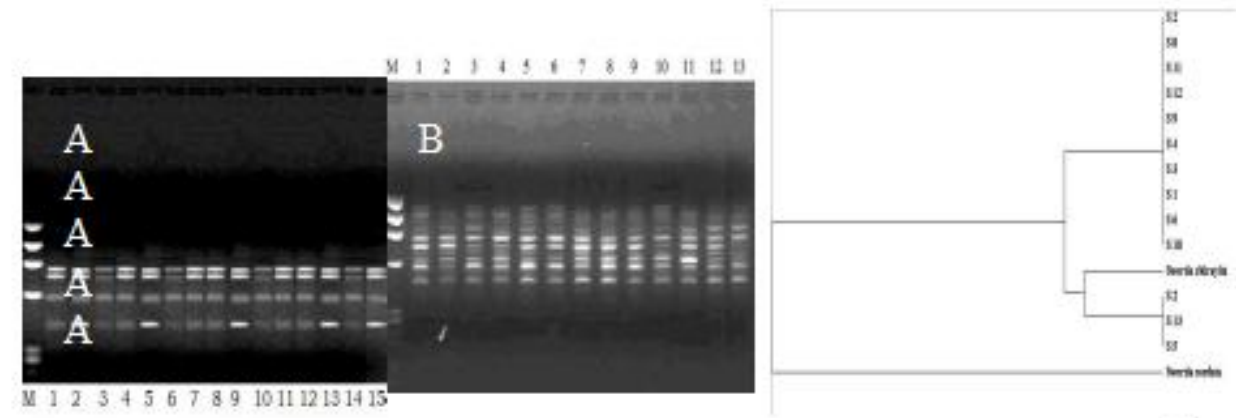

$\mathrm{C}$

Figure 2 RAPD fingerprinting pattern generated with primers M-119 (A) and OPB-4 (B) among the in vitro raised regenerants when compared with the donor plant. Lane (M) molecular weight marker $\phi$ X174 Hae III digest lambda DNA, lane (1) donor plant, lane (2-16) micropropagated shoots (C) Dendogram generated by UPGMA cluster analysis for similarity matrix obtained by Jaccard's genetic distance for 13 random samples obtained by in vitro propagation of Swertia chirayita Obtained by 30 random primers when compared with Swertia chirayita mother explant and $S$. cordata as an outlier.

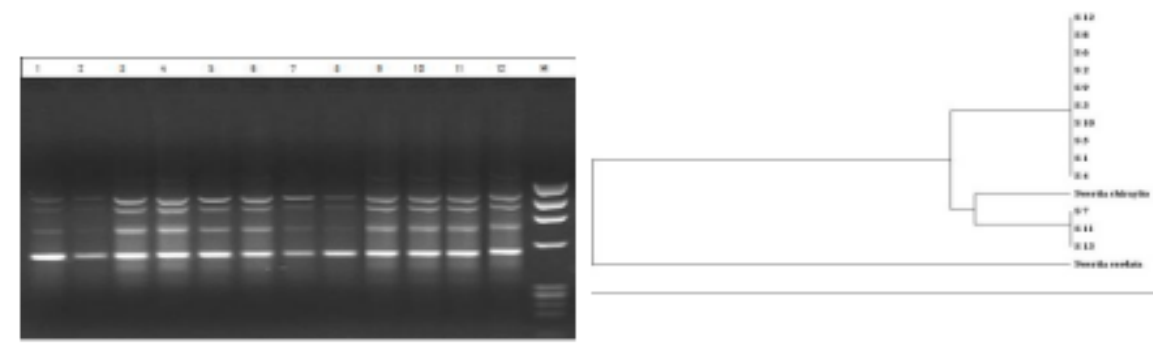

$3 \mathrm{~A}$

3 B

Figure 3 3A: ISSR profile of random samples of Swertia chirayita as amplified by UBC 818: Molecular marker lane $\phi X 174$ Hae III digest. 3B Dendogram generated by UPGMA cluster analysis for similarity matrix obtained by Jaccard's genetic distance for 13 random samples of Swertia chirayita Obtained by ISSR primers when compared with Swertia chirayita mother ex-plant and $S$. cordata as an outlier.

\section{DISCUSSION}

The present investigation deals with the development of tissue culture process for cloning of Swertia chirayita and validating the same through molecular markers at the same time. The results obtained are discussed step wise in the light of existing literature. The effect of BAP was found to be conducive with respect to the induction and number of shoots in initial phase of culture establishment. The results were found to be in agreement with the previous reports that have showed a significant effect of BAP and other cytokinins for axillary bud proliferation ${ }^{12}$. Similarly, in Anethum graveolens axillary shoots were promoted in BAP alone or in combination with other cytokinins ${ }^{21}$. It was also reported in Alocasia amazonica that cytokinins are responsible for optimal shoot bud proliferation and the addition of auxins could not promote shoot proliferation efficiency ${ }^{22}$. This may be due to the interaction of auxins with cytokinins during morphogenetic events as reported by Sato and Mori $(2001)^{23}$. For multiple shoot induction BAP played a key role. Similar results were observed in Ormocarpum sennoides $^{24}$, Adhathoda vasica ${ }^{25}$ and Chlorophytum borivilianum ${ }^{26}$. The superiority of 
BAP has been suggested over other cytokinins and auxins on medicinal plants, ${ }^{6,27-28}$. The effects of higher concentration of cytokinins have been reported to reduce the number of shoots generated per explant ${ }^{29,30}$. In the present study the use of higher concentrations of $\mathrm{Kn}$ and $2 \mathrm{iP}$ has been replaced with the augmentation of adenine sulphate at much lower concentration resulting in higher multiplication fold (9.75). Despite the fact that nitrates and ammonium salts have been widely used in the conventional in vitro protocols as nitrogen source, many reports suggests the use of reduced nitrogen forms particularly adenins and amino acids. These additives can adjust the nitrogen utilization of in vitro grown culture by regulating primary nitrogen assimilation and can improve cell proliferation as well as regeneration in many species ${ }^{31,32}$. Thus reduction of cytokinin supplementation results in the occurrence of reduced adventitious buds and thus reducing the chance of somaclonal variations. By analyzing the peroxidase profiling it is observed that in the later stages of multiplication there was less tissue damage, this may be due to less $\mathrm{H}_{2} \mathrm{O}_{2}$ accumulation due to increased activity of peroxidase. The results are in agreement with other reports on in vitro grown plants ${ }^{11,12,21,33}$. Bonfill et al. (2003) reported that peroxidase activity was related to the organogenic capacity in Panax ginseng ${ }^{34}$.

In micropropagated plants, there is always a risk of genetic variations. These variations have been confirmed using various DNA marker techniques, e.g. RAPD ${ }^{35,36}$. The RAPD technique has become an increasingly popular tool in genetic studies and in making genetic linkage maps for plant species. The RAPD technique can yield a large number of loci, thereby producing a more representative sample of the genome than is possible with allozyme. RAPDs are the least time consuming and the simplest to apply of the DNA based markers. Genetic similarity of micropropagated plants using RAPD markers have been reported in Chlorophytum borivilianum ${ }^{37}$, in Capparis decidua $^{38}$ and in Curcuma species ${ }^{39}$ and in Marsilea quadrifolia L. ${ }^{40}$. Although the preliminary investigation for assessing the genetic diversity were based on the use of RAPD markers that could be limited for its reproducibility and artifactual variations, therefore ISSR markers have been used to overcome this disadvantage to an extent. These marker systems provide a convenient and rapid assessment of the differences in genetic composition of closely related individuals at the DNA level and have been employed in a large number of plant species for characterization and assessment of genetic diversity and fidelity because of their speed and ease in handling ${ }^{41}$. A possible explanation for the difference in resolution of RAPDs and ISSRs is that the two markers techniques target different positions of the genome. It also concluded that the genetic purity/fidelity was further confirmed as these two marker systems amplify the different regions of genome and allow better chances for identification of genetic variations within the clones ${ }^{42}$ in the present study.

Production of genetically true to type plants is a prerequisite for the conservation and propagation of the plant. The present protocol provides the clear genetic status of the in vitro raised propagules where the fidelity of the plants was maintained throughout the stock.

\section{CONCLUSION}

To conclude, these results will encourage largescale micropropagation of this important herb in a short span of time with limited use of hormones. Study of antioxidant enzymes during organogenesis reveals that these enzymes play a significant role during organogenesis of this plant species and can be exploited for modification of media for mass propagation in other economically important medicinal plant species also. Further ISSR/RAPD analysis confirmed that the regenerated plants were genetically identical to their mother plant. It is suggested that RAPD/ISSR should be considered to screen and develop more suitable and tightly linked markers for improved traits and its further utilization in plant improvement and breeding programmes for exploitation of genetic resources for the sake of commercial and academic needs.

\section{REFERENCES}

1. Joshi P, and Dhawan V. Swertia chirayita - an overview. Curr Sci. 2005; 89 (4): 635-640.

2. Shekhawat GS, Mathur S, Batra A .Role of phytohormones and various nitrogen inorganic and organic nutrients in induction of somatic embryogenesis in cell culture derived from leaflets of Azadirachta indica A. Juss. Biol Plantarum. 2009; 53: 707-710. 
3. Shekhawat GS, Verma K, Jana S, Singh K, Prasad A. In vitro biochemical evaluation of cadmium tolerance mechanisms in callus and seedlings of Brassica juncea. Protoplasma.2010; 239: 31-38.

4.Jana S, and Shekhawat GS. Critical review on medicinally potent plant species: Gloriosa superba. Fitoterapia.2010; 82: 293-301.

5. Ahuja A, Koul S, Kaul BL, Verma NK, Kaul MK, Raina RK \& Qazi GN. Media compositions for faster propagation of Swertia chirata.2003; WO 03/045132 A1.

6.Joshi $\mathrm{P}$ and Dhawan V.Axillary multiplication of Swertia chirayita (Roxb. Ex Fleming) H. Karst., a critically endangered medicinal herb of temperate Himalayas. In Vitro Cell Dev Bio-Pl. 2007; 43:631638.

7.Chaudhuri RK, Pal A and Jha TB .Production of genetically uniform plants from the nodal explants of Swertia chirayita Buch.-Ham. ex Wall.- an endangered medicinal herb. In Vitro Cell Dev Bio-Pl. . 2007; 43 (5): 467-472.

8. Benson EE. Do free radicals have a role in plant tissue culture recalcitrance? In Vitro Cell Dev Bio-Pl.2000; 36: 163-170.

9. Mathur S, Shekhawat GS, Batra A. Micropropagation of Salvadora persica via cotyledonary nodes. Ind J Biotech.2000; 1(2): 197-200.

10. Mathur S, Shekhawat GS, Batra A .An efficient in vitro method for mass propagation of Salvadora persica via apical meristem. J Biochem Biotechnol.2000; 11: 125-127.

11. Dutta GS and Datta S. Antioxidant enzyme activities during in vitro morphogenesis of gladiolus and the effect of application of antioxidants on plant regeneration. Biol Plantarum. 2003;47:179-183.

12. Meratan AA, Ghaffari SM, Niknam V. In vitro organogenesis and antioxidant enzymes activity in Acanthophyllum sordidum. Biol Plantarum.2009; 53: 5-10.

13. Misra P, Pandey V, Kochhar S. Study of antioxidant enzymes activity during organogenesis and in vitro propagation of Asiatic hybrid lily. J Plant Biochem Biotechnol. 2010; 19: 119-122.

14. Sharifi $G$ and Ebrahimzadeh H. Changes of antioxidant enzyme activities and isoenzyme profiles during in vitro shoot formation in saffron (Crocus sativus L.). Acta Biol Hung.2010; 61: 73-89.

15. Murashige T and Skoog F. A revised medium for rapid growth and bioassays with tobacco tissue culture. Physiol Plantarum. 1962; 19:473-497.

16. Lowry OH, Rosebrough NJ, Farr AL and Randall RJ. Protein measurement with the folin phenol reagent. Jour Biol Chem. 1951; 193: 265.

17. Demetrios P, Griforios D, Miltiadis V Arbutin oxidation by pear (Pyrus communis L.) peroxidases. Plant Sci.2002; 162: 115-119.

18. Sharma V, Srivastava N, Kamal B, Dobriyal AK and Jadon VS. Isolation of PCR Compatible DNA from Swertia chirayita. Asian Jour Micro Biotech Env Sci. 2010; 12: 677-680.

19. Williams JGK, Kubelik AR, Livak KJ, Rafalski JA, Tingey SV. DNA polymorphism amplified by arbitrary primers are useful as genetic markers. Nucleic Acid Res. 1990; 18: 6531-6535.

20. Joshi P and Dhawan V. Assessment of genetic fidelity of micropropagated Swertia chirayita plantlets by ISSR marker assay. Biol Plantarum.2008; 51:2226.

21. Jana $\mathrm{S}$ and Shekhawat GS. In vitro regeneration of Anethum graveolens, antioxidative enzymes during organogenesis and RAPD analysis for clonal fidelity. Biol Plantarum. 2012; 56 (1): 9 14.

22. Jo VA, Murthy HN, Hahn EJ, Paek KY. Micropropagation of Alocasia amazonica using semisolid and liquid cultures. In Vitro Cell Dev BioPl. 2008; 44: 26- 32.

23. Sato SS and Mori H. Control in outgrowth of dormancy in axillary buds. Plant Physiol. 2001; 127: 1405-1413.

24. Shanthi P. In vitro propagation of Ormocarpum sennoides (Willd.) Dc. Prodr. from shoot tip explant. Ind J Plant Physiol. 2008; 13: 2932 .

25. Sangeetha $\mathrm{N}$ and Buragohi AK. Micropropagation of Adhathoda vasica Nees, a woody medicinal plant, by shoot tip culture. Ind $J$ Biotechnol. 2004; 4: 396-399.

26. Kumar A, Aggarwal D, Gupta P, Reddy MS. Factors affecting in vitro propagation and field establishment of Chlorophytum borivilianum. Biol Plantarum. 2010; 54: 601-606.

27. Dave A, Bilochi G and Purohit SD. Scaling-up production and field performance of micropropagated medicinal herb 'Safed Musli' (Chlorophytum borivilianum). In Vitro Cell Dev Bio-Pl. 2003; 39:419-424.

28. Martin KP. Rapid in vitro multiplication and ex vitro rooting of Rotula aquatica Lour., a rare rhoeophytic woody medicinal plant. Plant Cell Rep. 2003; 21:415-420.

29. Vincent KA, Mathew KM and Hariharan M. Micropropagation of Kaempferia galanga L.-a medicinal plant. Plant Cell Tiss Org. 1992; 28:229230.

30. Wawrosch C, Maskay N and Kopp B. Micropropagation of the threatened Nepalese medicinal plant Swertia chirata Buch.-Ham.ex Wall. Plant Cell Rep. 1999; 18: 997-1001.

31. Shrivastava S and Banerjee M. In vitro clonal propagation of physic nut (Jatropha curcas L.): influence of additives. Int J Integ Biol. 2008; 3: 73-79.

32. Sharma V, Kamal B, Srivastava N, Dobriyal AK, Jadon V. Effects of Additives in Shoot Multiplication and Genetic Validation in Swertia 
chirayita revealed through RAPD Analysis. Plant Tiss Cult Biotech. 2013; 23(1):11-19.

33. Vatankhah E, Niknam V, Ebrahimzadeh H. Activity of antioxidant enzyme during in vitro organogenesis in Crocus sativus. Biol Plantarum. 2012; 54:509-514.

34. Bonfill M, Cusido RM, Palazon J, Canut E, Pinol TM, Morales C. Relationship between peroxidase activity and organogenesis in Panax ginseng calluses. Plant Cell Tiss Org. 2003; 73: 3741.

35. Padmesh P, Reji JV, Jinish Dhar M, Seeni S. Estimation of genetic diversity in varieties of Mucuna pruriens using RAPD. Biol Plantarum. 2006; 50: 367372.

36. Zhang HQ and Zhou YH. Genetic relationships among Hystrix patula, $H$. duthiei and $H$ longearistata according to meiotic studies and genome-specific RAPD assay. Biol Plantarum. 2009; 53: 45-52.

37. Samantaray S and Maiti S. An assessment of genetic fidelity of micropropagated plants of Chlorophytum borivilianum using RAPD markers. Biol Plantarum. 2010; 54: 334-338.

38. Tyagi $\mathrm{P}$, Khanduja $\mathrm{S}$, Kothari SL. In vitro culture of Capparis decidua and assessment of clonal fidelity of the regenerated plants. Biol Plantarum.2010; 54: 126-130.

39. Das A, Kesari V and Rangan L. Plant regeneration in Curcuma species and assessment of genetic stability of regenerated plants. Biol Plantarum.2010; 54: 423-429.

40. Rolli E, Brunoni F, Marieschi M, Torelli A, Ricci A. In vitro micropropagation of the aquatic fern Marsilea quadrifolia L. and genetic stability assessment by RAPD markers. Plant Biosystems. 2015; 149(1):7-14.

41. Lakshmanan V, Venkataramareddy SR, Nellwarne B (2007). Molecular analysis of genetic stability in long-term micropropagated shoots of banana using RAPD and ISSR markers. Electronic $J$ Biotech. [online]. 15 January 2007, Vol. 10(1). DOI: 10.2225/vol10-issue5-fulltext-12.

http://www.ejbiotechnology.info/content/vol10/issue1 /full/12/

42. Martins M, Sarmento D, Oliveira MM. Genetic stability of micropropagated almond plantlets as assessed by RAPD and ISSR markers. Plant Cell Rep.2004; 23: 492-496. 